\title{
CHLORPYRIFOS INDUCED CHANGES ON THE PHYSIOLOGY OF COMMON CARP (CYPRINUS CARPIO LINNAEUS, 1785): A LABORATORY EXPOSURE STUDY
}

\author{
YancheVA, V. ${ }^{1}$ - VelcheVA, I. ${ }^{1}-$ Georgieva, E. ${ }^{2 *}-\operatorname{Mollov}, \mathrm{I}^{1}{ }^{-}$Stoyanova, ${ }^{2}{ }^{2}$ \\ ${ }^{1}$ Department of Ecology and Environmental Conservation, Faculty of Biology \\ Plovdiv University, Plovdiv, Bulgaria \\ ${ }^{2}$ Department of Developmental Biology, Section of Histology and Embryology \\ Faculty of Biology, Plovdiv University, Plovdiv, Bulgaria \\ *Corresponding author \\ e-mail: e_tomova@abv.bg; phone: +359-32-261-535 \\ (Received $14^{\text {th }}$ Jan 2019; accepted $26^{\text {th }}$ Feb 2019)
}

\begin{abstract}
The present study was designed to study the effects of the pesticide chlorpyrifos (CPF) on the physiology of the economically important fish species common carp (Cyprinus carpio Linnaeus, 1785) by applying a biomarker approach. This pesticide is considered as a priority substance in surface waters according to Directive 2013/39/EU of the European Parliament and of the Council. The fish were treated with decreasing concentrations of CPF for 72 hours (acute exposure) and the histological structure of gills and respiration rate were examined. In sum, we found pronounced alterations in the gill structure and changes in the respiration rate index, regardless of the applied pesticide concentrations which indicates its negative effects on non-target aquatic species such as common carp. The results from such studies could be incorporated in the legislation to prevent water contamination in areas with intensive agricultural practices by applying biomarkers, and an update could also be initiated on the maximum permissible concentrations of CPF in surface waters.
\end{abstract}

Keywords: biomarkers, fish, gills, histology, pesticides

\section{Introduction}

The increasing use of pesticides in agricultural activities for controlling pests and diseases attacking agricultural crops is considered a major problem worldwide. However, after their application, these compounds migrate to the aquatic environment mainly by drift and transportation via air, and runoff from agricultural set ups (Marino and Ronco, 2005). Currently, pesticides are also commonly used in several other areas such as livestock and households (Fevery et al., 2016). In addition, according to Katsumata et al. (2006) in recent years, more than 10,000 chemicals have been used for industrial and agricultural purposes. After prohibiting the use of organochlorine (OCs) insecticides, the organophosphorus insecticides (OPs) have become the most commonly used compounds worldwide.

Chlorpyrifos (O, O-diethyl O-(3, 5, 6-trichloro-2-pyridyl) phosphorothioate; $\mathrm{CPF}$ ) is a moderately toxic broad-spectrum lipophilic OP insecticide (Kow of 4.7) (Mugni et al., 2016) and one of the several OP compounds developed in the 1960s to replace persistent OC pesticides (Kumar et al., 2017). Today it is the most intensively used OP pesticide in agriculture. CPF is commonly used to control foliage and soil-borne insect pests on a variety of crops including rice, cotton, fruit, vegetable crops, lawns and ornamental plants, as well as subterranean termites (Rao et al., 2005; Fang et al., 2008). The urban uses of CPF include landscape maintenance, structural pest control, 
dormant sprays and pet products (Solomon et al., 2014). However, according to Humphrey et al. (2004) its usage is restricted in inhabited areas. The highest amount of CPF produced globally (3.64-4.99 million $\mathrm{kg}$ ) was recorded in 2007 (Grube et al., 2011). In India, it was reported that CPF was the second most used agricultural insecticide (9540 tons) in 2013-2014 (Kumar et al., 2017). In addition, this pesticide is one of the most widely used OPs in Argentina (Asselborn et al., 2015). As other OP insecticides, the primary site of action of CPF in animals is the acetylcholinesterase enzyme which is inactivated by phosphorylation, thereby interfering with normal cholinergic nerve transmissions (USEPA, 1986). Moreover, acetylcholinesterase plays an important role in neurotransmission at cholinergic synapses by rapid hydrolysis of neurotransmitter acetylcholine to choline and acetate (Kwong, 2002).

Aquatic species can be exposed to various OP pesticide concentrations which range from lethal to sublethal (Streit and Kuhn, 1994). Few reports are available on the effects of CPF on non-target aquatic organisms and some authors demonstrated its adverse effects on aquatic invertebrates and fish. Varó et al. (1998) pointed out $\mathrm{EC}_{50}$ values ranging from 0.95 to $18 \mathrm{mg} \mathrm{l}^{-1}$ of CPF in several Artemia species. Earlier reports also revealed fish kill incidents in association with $\mathrm{CPF}$ in water reaching several hundred parts per billion (Abdel-Halim et al., 2006). According to Varó et al. (1998) CPF passes via air-drift or surface runoff into natural waters, where it is accumulated in different aquatic organisms, especially in fish, making it vulnerable to several discernible effects. Thus, it is found that CPF is estrogenic and alters embryonic hatching, cell proliferation and apoptosis in Zebra fish (Yu et al., 2015); it affects the sex steroid production and thyroid follicular development in adult and larval lake sturgeon (Brandt et al., 2015); as well as the acetylcholinesterase activity in climbing perch and Zebra fish (Nguyen et al., 2015) and the activity of glucose-6phosphate dehydrogenase in rainbow trout (Topal et al., 2014); it causes oxidative stress in common carp and Zebra fish (Chen et al., 2015); it impacts the protein synthesis in Zebra fish (Liu et al., 2015) and DNA and RNA synthesis in common carp (Wang et al., 2014), and causes histopathological alterations in common carp (Xing et al., 2012). Moreover, CPF is known to change the lysosomal membrane stability in other aquatic species such as Zebra mussel (Yancheva et al., 2017a,b).

A biomarker is known to be a change in a biological response, either at molecular, cellular, histological, physiological or behavioral level that can be related with the exposure to toxic environmental elements (Colin et al., 2016). One advantage of biomarkers relative to bioindicators is that the former allow examining specific target organs and cells, including gills, kidney and liver which are affected by exposure to environmental chemicals and are responsible for vital functions such as respiration, excretion and the accumulation and biotransformation of xenobiotics (Van der Oost et al., 2003).

According to Varó (1998) the histopathological effects produced in different tissues of non-target organisms are usually used to biomonitor polluted areas and environmental conditions in aquaculture systems, and the use of histopathological biomarkers in biomonitoring has many advantages. As stated by Hinton and Laurén (1990) the histological effects are consequences of biochemical mechanics that provide interpretative power about damage effects to individuals done at the molecular level. These biomarkers can be used as an early warning system for potential effects at the level of the individual. In addition, the histopathological lesions are easily recognizable alterations that ideally indicate alone a pathological condition, 
also reflecting the severity and duration of pollution events. Although they cannot reveal toxic identity, the histological biomarkers can identify the pollution type through its mode of action, further supporting the use of histopathological biomarkers as faithful indicators of environmental pollution (Colin et al., 2016).

The gills of aquatic animals are usually used to assess pollution effects, as they are the first organ which comes in contact with the aquatic pollution. They are also highly vulnerable to toxic chemicals, mainly because their large surface area facilitates the interaction and their absorption. The toxicant absorption through gills is rapid and therefore, the toxic response in gills is also rapid (Pandey et al., 2008; Topal et al., 2015). Moreover, the histological lesions of gills are frequently the consequence of exposure to various contaminants (Fonseca et al., 2016) with the severity being dependent on the pollutant concentration and exposure time span (Tchounwou et al., 2012). Last but not least, the gill histopathological changes were previously recognized as valuable biomarkers of water ecosystem stressors (Pereira et al., 2013; Cruz et al., 2015).

According to Chen and Yang (2007), Dobreva et al. (2008), and Nishida (2011) the toxic effects of different pollutants may be linked to changes in the respiration rate and may also be used as an indicator of polluted waters. These changes are associated with insufficient amount of oxygen in the water, causing stress to the aquatic organisms. In addition, the rate of respiration reflects the metabolic activities of organisms and the responses due to changes in the surrounding environment could also serve as an indicator of adjustment capacity (Kumar et al., 2012).

The fish communities are key elements to evaluate the ecological condition of different water bodies based on biomarkers (Hermoso and Clavero, 2013), while histopathology is the standard method for assessing both short- and long-term xenobiotic effects on fish (Hinton and Lauren, 1990). What is more, to face environmental problems Water Framework Directive (WFD, Directive 2000/60/EC) has driven the need to assess the ecological status of water bodies through an integrative ecosystem approach using elements of biotic quality such as bioindicators. Along with diatoms, macroinvertebrates and macrophytes, the fish are key elements to assess the ecological status of water aquatic ecosystems (Fonseca et al., 2017).

Since 2000, aquaculture has been growing 6\% per year and now has become a major food industry in the world market, as well as an important source of meat in the human diet (FAO, 2016). Common carp (Cyprinus carpio, Cyprinidae) which belongs to the omnivorous fish is one of the most important commercial species in aquaculture with a successful spread all over the world, and it is also highly valued in many different areas of biology (Kong et al., 2018). According to Zoral et al. (2017) common carp is a major cultured fish species, accounting for $10 \%$ of freshwater aquaculture production worldwide. Furthermore, common carp is introduced as one of the most suitable fish models for toxicological studies (OECD, 1992). The dominance of common carp in the aquatic systems and the fact that it has a better capacity for resistance against pollutants rather than other laboratory fish, such as Zebra fish and Japanese medaka are common reasons for choosing this exact species in toxicological tests (Lee et al., 2012; Pirsaheb et al., 2019).

Based on the above, in terms of aquatic toxicology it is essential to study the effects of CPF which is considered as a priority substance in surface waters according to Directive 2013/39/EC of the European parliament and the Council on non-target organisms, such as fish. Hence, the main objective on the present work was to study 
the possible negative effects of a short-term exposure ( 72 hours) of decreasing and environmentally relevant concentrations of CPF on the physiology of common carp by applying a biomarker approach as we hypothesized that we would also observe changes in the fish at lower concentrations than the permitted annual average concentrations in surface waters. Thus, we aimed to semi-quantitatively assess the gill histology through a histology-based fish health protocol and to measure the respiration rate.

\section{Materials and methods}

\section{Experimental set up}

Common carps with no external lesions were obtained from the Institute of Fisheries and Aquaculture, located in the city of Plovdiv, Bulgaria where fish are reared under strict and controlled conditions. They were weighed ( $\mathrm{g}$; total weight including viscera) and the total length $(\mathrm{cm})$ were recorded $(22.5 \mathrm{~g} \pm 3.5 ; 13.5 \mathrm{~cm} \pm 2.5)$. The fish were transported in plastic tanks equipped with air pumps to the laboratory of Faculty of Biology, Plovdiv University, Bulgaria. After transportation they were moved in glass tanks with 1001 chlorine free tap water (by evaporation) to acclimatize for a week. All tanks were equipped with air pumps for permanent aeration and the water was kept oxygen saturated. The fish were kept under a natural light/dark cycle (12:12) and they were not fed prior to the experiment. The fish were divided into four test groups $(n=15)$, including the control. Thereafter, they were treated with different and decreasing (environmentally relevant) soluble concentrations of CPF, dissolved in cyclohexane for 72 hours (acute, short-term experiment). According to the national and EU legislation the annual average concentrations (AA-EQS) of CPF in inland surface waters and other surface waters is $0.03 \mu \mathrm{g} \mathrm{l}^{-1}$. The tested concentrations were prepared as 50 and $30 \%$ of the AA-EQS. The reason for this selection is that the natural waters are usually contaminated with organic substances in low concentrations which subsequently lead to chronic exposure effects for the aquatic organisms. Therefore, in the current experiment

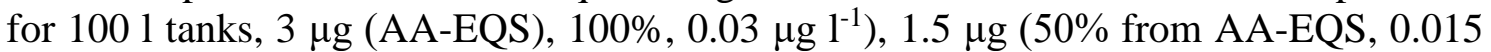
$\left.\mu \mathrm{g}^{-1}\right)$ and $0.9 \mu \mathrm{g}\left(30 \%\right.$ from AA-EQS, $\left.0.009 \mu \mathrm{g} \mathrm{l}^{-1}\right)$ were applied. No fish mortality was observed. The basic physical characteristics of the water such as: $\mathrm{pH}$, temperature, oxygen level and conductivity were followed strictly three times on the $24^{\text {th }}, 48^{\text {th }}$ and $72^{\text {nd }}$ hour according to a standard procedure (APHA, 2005) with a combined field-meter (WTW, Germany). All experiments were conducted in accordance with the national and international guidelines of the European Parliament and the Council on the protection of animals used for scientific purposes according to Directive 2010/63/EU.

\section{Histological techniques}

Fish dissection was performed according to the international standard procedures given in the EMERGE Protocol (Rosseland et al., 2003). All histological were prepared according to a standard procedure for light microscopy analysis (Gautier, 2011). For each fish, the gills were sampled and preserved in $10 \%$ neutrally buffered formaldehyde for 24 hours. The preserved samples were washed in tap water, dehydrated in a series of increasing ethanol concentrations $(70 \%-80 \%-85 \%-96 \%-100 \%)$, cleared in xylene, infiltrated with liquid paraffin with a melting point of $54-56^{\circ} \mathrm{C}$ and finally embedded in paraffin wax. They were then sectioned $(5 \mu \mathrm{m}$ thick) on a rotary 
microtome (Leica RM2125 RTS, Germany) according to Humason (1962). The sections were stained with hematoxylin-eosin (H\&E) and observed with a light microscope (Leica DM 500, Germany). The glass slides were labelled and were examined "blind". Firstly, the histological lesions were assessed according to the semi-quantitative system proposed by Bernet et al. (1999). Briefly, according to this method the histological lesions were classified into three reaction patterns - circulatory, regressive and progressive changes. Each reaction pattern includes several alterations which concern either functional units of the organ or the entire organ (see Bernet et al., 1999). As we did not find any inflammatory or neoplastic (tumor) alterations, these reaction patterns were excluded. Secondly, a six degree (0-6) severity gradation scale (SGS) which represents the severity of each alteration was defined according to Saraiva et al. (2015). Each grade represents specific histological characteristics and is categorized as follows: (0) - no histological alterations which represented normal gill histological structure; (1) - mild histological alterations; (2) - moderate histological alterations; (3) - pronounced histological alterations; (4) - severe histological alterations and (5) - very severe histological alterations. The relevance of a lesion depends on its pathological importance, i.e. how it affects the organ function and the ability of the fish to survive. Therefore, the pathological extent of each lesion was defined with an importance factor according to Bernet et al. (1999) as follows: (1) - minimal pathological importance, the lesion is easily reversible as toxicant exposure ends; (2) - moderate pathological importance, the lesion is reversible in most cases if the stressor is neutralized and (3) marked pathological importance, the lesion is generally irreversible, leading to partial or total loss of the organ function. The final value for each alteration results from the multiplication of the score value with the importance factor. Summing up these final values for one reaction pattern or organ gives the index for the respective reaction pattern i.e. index for circulatory disturbance (IC), index for regressive changes (IR), index for progressive changes (IP) for the gills or organ index (OI). Organ index values were used to classify the severity of histological response using classes based in the scoring scheme proposed by Zimmerli et al. (2007): Class I (index $\leq 10)$ - normal tissue structure with slight histological alterations; Class II (index 11-20) - normal tissue structure with moderate histological alterations; Class III (index 21-30) - moderate modifications of normal tissue; Class IV (index 31-40) - pronounced histological alterations of the organ; Class V (index N 40) - severe histological alterations of the organ. The sum of the multiplied score values and importance factors of all diagnosed changes for each specimen resulting in different indices were statistically analyzed. The results were presented as averages. Besides the indices calculated by extent (score value) and pathological importance (importance factor) of lesions, a further point of interest to us was the prevalence of histological changes. Histological lesions were observed in each individual from the tested concentrations (15 individuals in concentration, 3 tested concentrations). From each individual 10 slides were prepared (10 slides $\mathrm{x} 15$ individuals $=150$ slides per concentration). From each slide approximately 100 lamellae were observed and the specific lesions were recorded. The prevalence was presented as average for all studied specimens for each concentration $(\mathrm{n}=15)$. We proposed the following classification: $(10-30 \%)$ - alterations which occurred rarely; (30-50\%) - alterations which occurred frequently; (50-70\%) alterations which occurred more frequently, and (>70\%) - alterations which prevailed in the gill histological structure. 


\section{Respiration rate measurements}

The respiration rate was measured along with the histological analysis on the $72^{\text {nd }}$ hour. At the given time 5 fish were transferred in 301 glass aquaria filled with water from the test tanks. The oxygen levels were measured using an oximeter (WTW, Germany). The tanks were filled with water until the edge and covered with plastic foil in order to prevent oxygen access from the air. The tanks were left for one hour and thereafter, the oxygen level was again measured. The respiration rate was determined by calculating the difference in the dissolved oxygen levels before and after one hour following Tsekov (1989): $\mathrm{I}=\mathrm{Q}_{2} / \mathrm{G}$ where $\mathrm{I}$ - respiration rate index; $\mathrm{G}$ - weight of the fish, $\mathrm{Q}_{2}$ - oxygen consumed by the fish between the two measurements (the difference between the oxygen levels before and after one hour $\mathrm{Q}_{2}=\mathrm{Q}_{-} \mathrm{Q}_{1}$ hour). $\mathrm{Q}$ was calculated by the following formula: $\mathrm{Q}=\mathrm{V} \times \mathrm{q}$, where: $\mathrm{Q}$ - total oxygen level in the tank; $\mathrm{V}-$ volume of the water in the tank; $\mathrm{q}-$ level of dissolved oxygen in one liter of water $\left(\mathrm{mg} \mathrm{l}^{-1}\right)$.

\section{Statistical analysis}

For the statistical processing of the data the software package Graph Pad Prism 7 for Windows (USA) was used, as well as the software package Past v. 3.0 (Hammer et al., 2001). The histological index results were presented as average values per tested group. The number of fish affected by a specific histological lesion was presented as percentage prevalence. The normal distribution was tested with the D'Agostino-Pearson normality test. T-test was applied to see if there is a significant difference between the histological alterations in the exposed groups and the control, as well as between the different lesions. Pearson's correlation index (r) was applied, using normalized data (square root transformation) when the data were not normally distributed (Fowler et al., 1998) in order to determine if there is correlation between the respiration rate and the pesticide concentrations. The index of determination $\left(\mathrm{r}^{2}\right)$ was also given. A level of probability $\mathrm{p}<0.05$ was considered as statistically significant.

\section{Results}

\section{Water quality}

The basic physical water quality parameters measured at the three tested concentrations are presented in Table 1. They did not differ significantly ( $p>0.05)$ compared to the control and were also within the acceptable water quality guideline ranges for aquatic ecosystems (DWAF, 1996).

Table 1. Basic water physical properties measured in the three CPF test tanks, including control

\begin{tabular}{c|c|c|c|c}
\hline Test tank & $\mathbf{p H}$ & $\mathbf{T}\left({ }^{\circ} \mathbf{C}\right)$ & Conductivity $(\boldsymbol{\mu S ~ c m - 1})$ & Dissolved oxygen $(\mathbf{m g} \mathbf{L}-\mathbf{1})$ \\
\hline $0.9 \mu \mathrm{g} \mathrm{CPF}$ & $8.3 \pm 0.5$ & $16.5 \pm 1.5$ & $370 \pm 5.5$ & $8.5 \pm 1.5$ \\
$1.5 \mu \mathrm{g} \mathrm{CPF}$ & $8 \pm 0.5$ & $17.3 \pm 2$ & $365 \pm 3.5$ & $8.3 \pm 0.3$ \\
$3 \mu \mathrm{g} \mathrm{CPF}$ & $7.5 \pm 1.5$ & $18.5 \pm 0.5$ & $410 \pm 0.5$ & $7 \pm 0.5$ \\
Control & $8.5 \pm 0.5$ & $19 \pm 0.5$ & $353.3 \pm 0.3$ & $9.1 \pm 1$ \\
\hline
\end{tabular}




\section{Gill histology}

No external abnormalities were identified on any of the common carps, both control and tested fish. The general gill structure of control carps was typical for teleostean (Evans et al., 2005). In addition, our results for the control carps corresponded to Rajeshkumar et al. (2017). The gills of the control group were characterized with normal morphology including primary and secondary lamellae. The gills had four gill arches on each side of the buccal cavity. Each arch was composed of numerous gill filaments which had two rows of secondary lamellae which ran perpendicular to each filament. Each lamellae was made up of two sheets of epithelium delimited by many pillar cells which were contractile and separate the capillary channels. The single-cell thick lamellar epithelia contained goblet and chloride cells. One to two erythrocytes were usually recognized within each capillary lumen. Therefore, based on the proposed scale we determined the gill histology of control common carp as relatively normal (0) (Fig. 1, Tables 2 and 3). However, the macroscopic examination of the common carp gills exposed to different CPF concentrations for 72 hours showed alterations which differed in type, severity and prevalence. These lesions are presented in Tables 2 and 3, and respectively in Figures 2, 3 and 4.

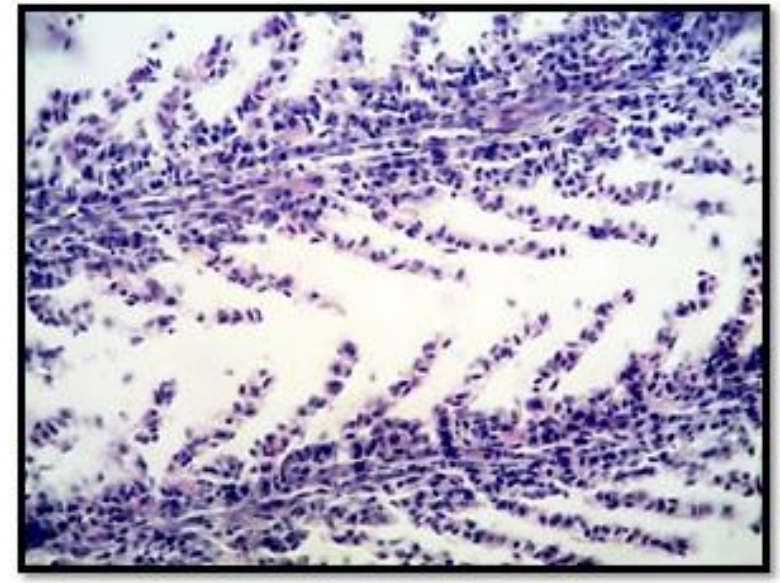

Figure 1. Histological structure of common carp gills, control, x 200, H\&E

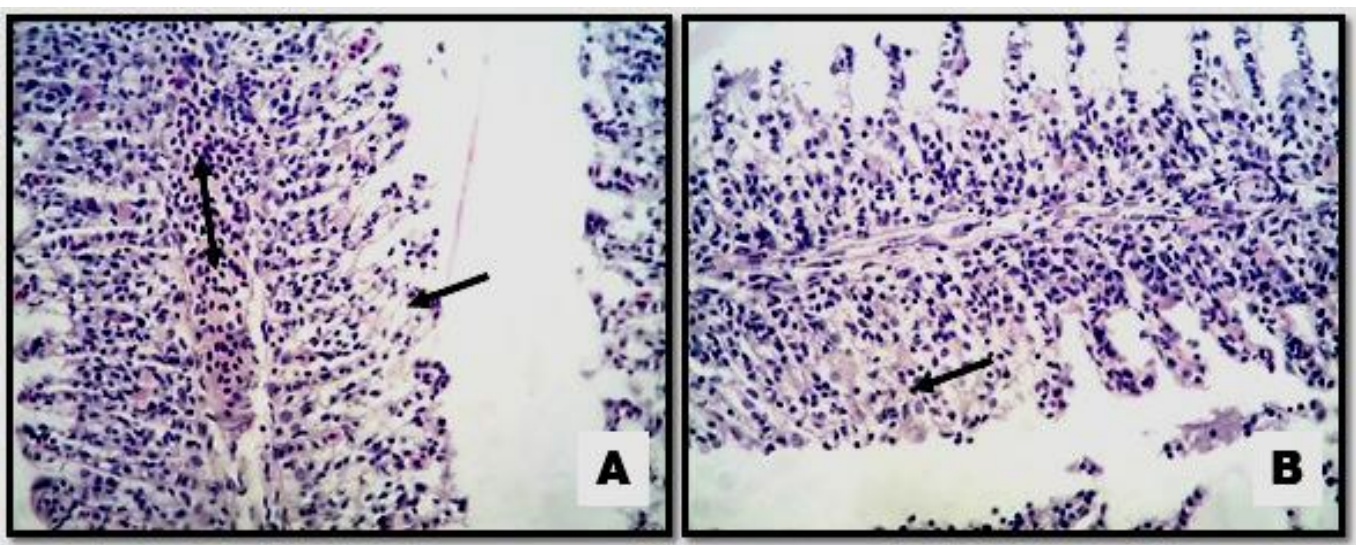

Figure 2. Histological alterations in common carp gills after exposure to $0.9 \mu \mathrm{g} C P F, x 400$, $H \& E: \boldsymbol{A}-$ Vasodilatation in the primary lamellae and lamellar lifting; $\boldsymbol{B}$ - Proliferation of gill epithelium and partial fusion 
Table 2. Histological assessment tool for common carp gills exposed to different CPF concentrations for 72 hours (average results; $n=15$ fish in each test tank)

\begin{tabular}{|c|c|c|c|c|c|c|c|c|c|c|c|}
\hline \multirow{2}{*}{$\begin{array}{l}\text { Gills reaction } \\
\text { pattern }\end{array}$} & \multirow{2}{*}{$\begin{array}{c}\text { Functional } \\
\text { unit of the } \\
\text { tissue }\end{array}$} & \multirow{2}{*}{ Alteration } & \multirow{2}{*}{$\begin{array}{l}\text { Importance } \\
\text { factor }\end{array}$} & \multicolumn{4}{|c|}{ Score value } & \multirow{2}{*}{\begin{tabular}{|c|c|} 
& $\begin{array}{c}\text { Index } \\
\text { control }\end{array}$ \\
$\mathrm{g}$ & \\
\end{tabular}} & \multirow{2}{*}{$\begin{array}{l}\text { Index } \\
0.9 \mu \mathrm{g}\end{array}$} & \multirow{2}{*}{$\begin{array}{l}\text { Index } \\
1.5 \mu \mathrm{g} \\
\end{array}$} & \multirow{2}{*}{\begin{tabular}{|c|} 
Index \\
$3 \mu \mathrm{g}$ \\
\end{tabular}} \\
\hline & & & & control & $0.9 \mu \mathrm{g}$ & $1.5 \mu \mathrm{g}$ & $3 \mu \mathrm{g}$ & & & & \\
\hline \multirow{4}{*}{$\begin{array}{c}\text { Circulatory } \\
\text { disturbances }\end{array}$} & \multirow{3}{*}{$\begin{array}{c}\text { Blood } \\
\text { vessels of } \\
\text { secondary } \\
\text { lamellae }\end{array}$} & \begin{tabular}{|c|}
$\begin{array}{c}\text { Vasodilatation } \\
\text { along the length } \\
\text { of the blood } \\
\text { vessel }\end{array}$ \\
\end{tabular} & $\mathrm{W}_{\mathrm{GCl}}=1$ & 0 & 1 & 2 & 2 & \multirow{4}{*}{$\mathrm{I}_{\mathrm{GC}}=0$} & \multirow{4}{*}{$\mathrm{I}_{\mathrm{GC}}=4$} & \multirow{4}{*}{$\mathrm{I}_{\mathrm{GC}}=9$} & \multirow{4}{*}{$\mathrm{I}_{\mathrm{GC}}=13$} \\
\hline & & \begin{tabular}{|c|}
$\begin{array}{c}\text { Vasodilatation } \\
\text { at the basal part } \\
\text { of the blood } \\
\text { vessel }\end{array}$ \\
\end{tabular} & $\mathrm{W}_{\mathrm{GC} 2}=1$ & 0 & 1 & 2 & 2 & & & & \\
\hline & & \begin{tabular}{|c|} 
Vasodilatation \\
at the apical part \\
of the blood \\
vessel
\end{tabular} & $\mathrm{W}_{\mathrm{GC} 3}=1$ & 0 & 0 & 1 & 1 & & & & \\
\hline & $\begin{array}{c}\text { Blood } \\
\text { vessels of } \\
\text { primary } \\
\text { lamellae }\end{array}$ & Vasodilatation & $\mathrm{W}_{\mathrm{GC} 4}=2$ & 0 & 1 & 2 & 4 & & & & \\
\hline $\begin{array}{c}\text { Regressive } \\
\text { lesions }\end{array}$ & Epithelium & $\begin{array}{c}\text { Degeneration } \\
\text { (necrosis) }\end{array}$ & $\mathrm{W}_{\mathrm{GRI}}=3$ & 0 & 0 & 1 & 2 & $\mathrm{I}_{\mathrm{GR}}=0$ & $\mathrm{I}_{\mathrm{GR}}=0$ & $\mathrm{I}_{\mathrm{GR}}=3$ & $\mathrm{I}_{\mathrm{GR}}=6$ \\
\hline \multirow{6}{*}{$\begin{array}{l}\text { Progressive } \\
\text { lesions }\end{array}$} & \multirow{2}{*}{$\begin{array}{c}\text { Epithelium } \\
\text { (secondary } \\
\text { lamellae) } \\
\end{array}$} & \begin{tabular}{|l|} 
Lamellar lifting \\
\end{tabular} & $\mathrm{W}_{\mathrm{GP} 1}=1$ & 1 & 2 & 4 & 4 & \multirow{6}{*}{$\mathrm{I}_{\mathrm{GP}}=1$} & \multirow{6}{*}{$\mathrm{I}_{\mathrm{GP}}=11$} & \multirow{6}{*}{$\mathrm{I}_{\mathrm{GP}}=34$} & \multirow{6}{*}{$\mathrm{I}_{\mathrm{GP}}=25$} \\
\hline & & Proliferation & $\mathrm{W}_{\mathrm{GP} 2}=2$ & 0 & 1 & 4 & 4 & & & & \\
\hline & \multirow{4}{*}{$\begin{array}{c}\text { Epithelium } \\
\text { (primary } \\
\text { lamellae) }\end{array}$} & Edema & $\mathrm{W}_{\mathrm{GP} 3}=1$ & 0 & 1 & 2 & 4 & & & & \\
\hline & & \begin{tabular}{|c|} 
Proliferation of \\
stratified \\
epithelium \\
\end{tabular} & $\mathrm{W}_{\mathrm{GP} 4}=1$ & 0 & 2 & 4 & 2 & & & & \\
\hline & & \begin{tabular}{|l|} 
Proliferation of \\
glandular cells
\end{tabular} & $\mathrm{W}_{\mathrm{GP} 5}=1$ & 0 & 1 & 4 & 4 & & & & \\
\hline & & Fusion & $\mathrm{W}_{\mathrm{GP} 6}=3$ & 0 & 1 & 4 & 1 & & & & \\
\hline Gill Index $\mathbf{I}_{\mathbf{G}}$ & & & & & & & & $I_{G}=1$ & $I_{G}=15$ & $I_{G}=46$ & $I_{G}=44$ \\
\hline
\end{tabular}

Table 3. Percentage prevalence of histological alterations in the common carp gills exposed to different $C P F$ concentrations for 72 hours

\begin{tabular}{|c|c|c|c|c|c|}
\hline \multirow{2}{*}{\multicolumn{2}{|c|}{ Histological alterations }} & \multicolumn{4}{|c|}{ Prevalence, \% } \\
\hline & & \multirow{2}{*}{$\begin{array}{c}\text { Control } \\
0\end{array}$} & \multirow{2}{*}{$\begin{array}{c}0.9 \mu \mathrm{g} \\
16\end{array}$} & \multirow{2}{*}{$\begin{array}{c}1.5 \boldsymbol{\mu g} \\
31\end{array}$} & \multirow{2}{*}{$\begin{array}{c}3 \mu \mathrm{g} \\
39\end{array}$} \\
\hline \multirow{4}{*}{$\begin{array}{l}\text { Circulatory } \\
\text { disturbances }\end{array}$} & $\begin{array}{l}\text { Vasodilatation along the length of the } \\
\text { blood vessel in the secondary lamellae }\end{array}$ & & & & \\
\hline & $\begin{array}{l}\text { Vasodilatation at the basal part of the } \\
\text { blood vessel in the secondary lamellae }\end{array}$ & 0 & 13 & 29 & 35 \\
\hline & $\begin{array}{l}\text { Vasodilatation at the apical part of the } \\
\text { blood vessel in the secondary lamellae }\end{array}$ & 0 & 0 & 19 & 23 \\
\hline & Vasodilatation of central venous sinus & 0 & 23 & 33 & 63 \\
\hline \multicolumn{2}{|r|}{ Average, $\%$} & $\mathbf{0}$ & 13 & 28 & 40 \\
\hline Regressive lesions & Degeneration (necrosis) & 0 & 0 & 16 & 53 \\
\hline \multicolumn{2}{|r|}{ Average, $\%$} & $\mathbf{0}$ & $\mathbf{0}$ & 16 & 53 \\
\hline \multirow{6}{*}{ Progressive lesions } & Lamellar lifting & 16 & 75 & 83 & 86 \\
\hline & $\begin{array}{l}\text { Proliferation of epithelium covering } \\
\text { secondary lamellae }\end{array}$ & 0 & 25 & 56 & 61 \\
\hline & Edema & 0 & 28 & 46 & 59 \\
\hline & Proliferation of stratified epithelium & 0 & 48 & 85 & 56 \\
\hline & Proliferation of glandular cells & 0 & 15 & 78 & 84 \\
\hline & Fusion & 0 & 21 & 69 & 25 \\
\hline \multicolumn{2}{|r|}{ Average, \% } & 2.7 & 35.3 & 69.5 & 61.8 \\
\hline
\end{tabular}



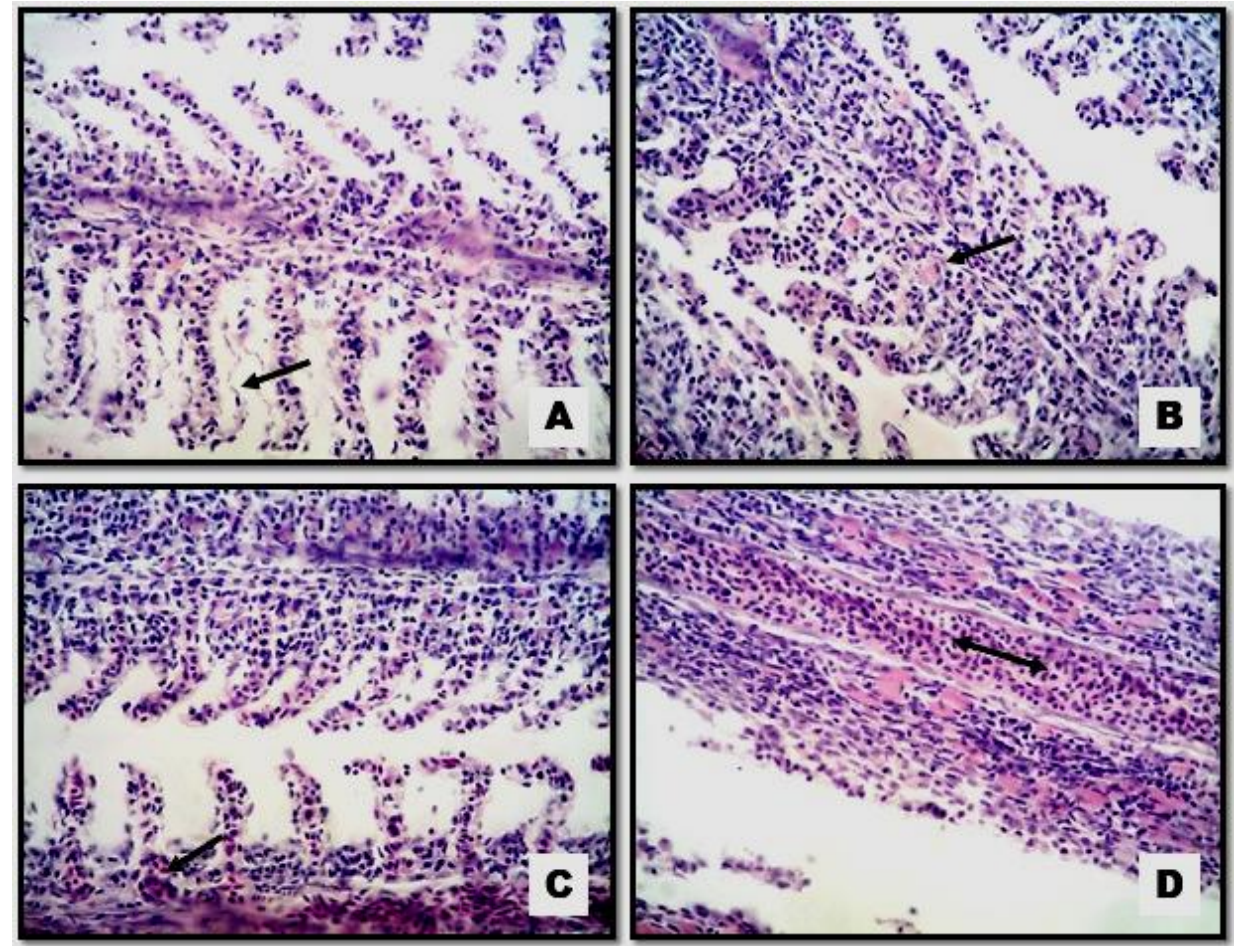

Figure 3. Histological alterations in common carp gills after exposure to $1.5 \mu \mathrm{g} C P F, x 400$, $H \& E: \boldsymbol{A}$-Lamellar lifting; $\boldsymbol{B}$-Proliferation of the glandular cells in the gill epithelium of the main lamellae; $\boldsymbol{C}$-Vasodilatation at the basal part of the blood vessel in the secondary lamellae; $\boldsymbol{D}$ - Vasodilatation of the primary lamellae
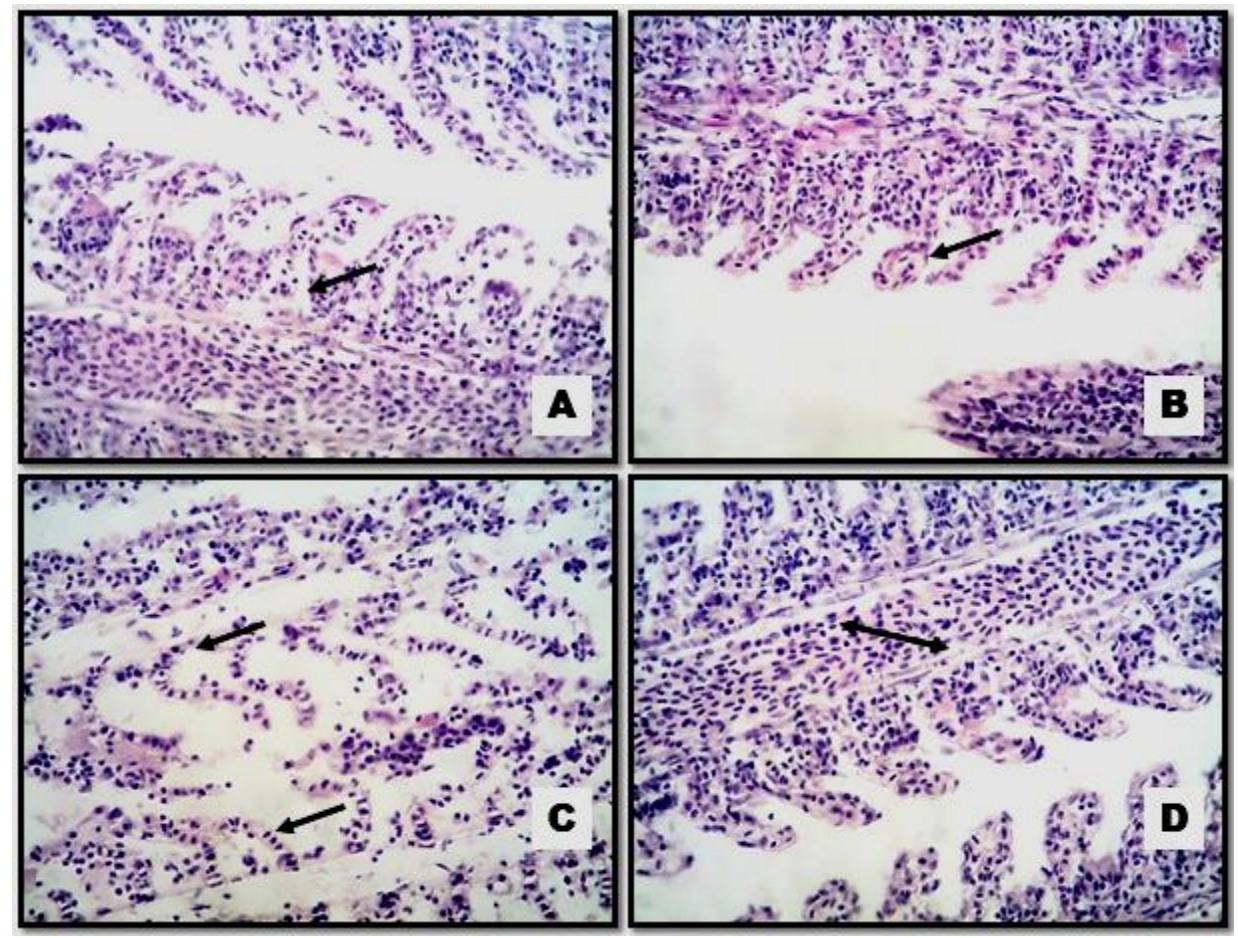

Figure 4. Histological alterations in common carp gills after exposure to $3 \mu \mathrm{g} C P F, x 400$, $H \& E: \boldsymbol{A}-E d e m a ; \boldsymbol{B}-$ Proliferation of the gill epithelium in the secondary lamellae; $\boldsymbol{C}-$

Degeneration of lamellar epithelium; $\boldsymbol{D}$-Vasodilatation of the primary lamellae 
Overall, from the conducted study on the negative effects of CPF on the histological structure of common carp gills alterations which we categorized overall in three groups - proliferative (progressive) changes, degenerative (regressive) changes in the gill epithelium and changes in the circulatory system (circulatory disturbances) were observed. We found that the proliferative alterations among the three groups were with the most severe degree of expression at all three tested concentrations, and these were lamellar lifting, edema, epithelial proliferation covering the primary and secondary lamellae, glandular cell proliferation (Table 2). Furthermore, these alterations showed an increase in the degree of expression in line with the increase in the pesticide concentration, except the proliferation of filament epithelium and fusion. These changes were expressed in a higher degree at the CPF concentration of $1.5 \mu \mathrm{g}$. We observed the most severe proliferative alteration, fusion, in the area of the secondary lamellae which completely altered the structure of the studied organ. Proliferation of epithelial tissue covering the filament reached the tip of the lamellae, whereby the individual secondary lamellae were not distinguishable. In general, fusion was presented at all tested concentrations, but its most severe degree of expression was detected at the CPF concentration of $1.5 \mu \mathrm{g}$ (Table 2). This in turn, probably demonstrates the inclusion of active cell division processes associated with compensatory-adaptive mechanisms against the entry of the toxicant at this concentration.

The observed degenerative changes also showed an increase in the degree of expression along with the increase in the CPF concentration. However, degeneration of epithelial cells in the filament and secondary lamellae was not found at the lowest applied concentration $(0.9 \mu \mathrm{g})$. On the other hand, at the same CPF concentration we observed a more active manifestation of proliferative changes in the gill epithelium which was also confirmed by the presence of fusion expressed in a mild degree of expression. At a CPF concentration of $1.5 \mu \mathrm{g}$ the proliferative changes prevailed over the degenerative ones, with a severe degree of fusion which covered the majority of the secondary lamellae. In contrast, the degenerative changes were found to a mild extent (Table 2). This in turn, also shows a more active inclusion of compensatory-adaptive responses expressed through cell division processes compared to the lesser expression of necrotic processes in the common carp gills. At the highest applied concentration which equals AA-EQS of CPF in surface waters $(3 \mu \mathrm{g})$, unlike the previous ones, we found predominant degenerative changes associated with more active involvement of necrotic processes in the gill epithelium. There was also a gradual substitution of the degenerative over the proliferative lesions associated with necrotic processes which showed a more severe degree of damage at the highest concentration, most likely due to the higher toxicity of CPF.

The changes found in the gill circulatory system consisted of vasodilatation in the main sinus and the blood vessels in the secondary lamellae. Similarly to the proliferative and degenerative changes in the gill epithelium these alterations also showed a certain tendency to increase the degree of expression with increasing the CPF concentration. At the lower applied concentrations $(0.9 \mu \mathrm{g})$ vasodilatation of the secondary lamellae was found in their basal part, with a mild degree of expression (Table 2). Basal sinus vasodilation was observed in a severe degree of expression at the highest CPF concentration, probably indicating an increase in the internal blood vessel volume associated with red blood cell influx.

Overall, the occurred changes limited to the severe degree of expression which we linked with the particular exposure time of 72 hours. As for the very severe degree of 
histological alterations, we consider that a longer exposure period is required which in turn is associated with further thorough studies.

The statistical analysis showed a significant difference $(\mathrm{p}<0.05)$ between the score value for the control and the three groups of alterations (circulatory disturbances, progressive and regressive lesions) observed in the fish gills exposed to the highest CPF concentration. No significant differences were found for the reaction patterns between the different tested CPF concentrations.

The mean gill index $\left(\mathrm{I}_{\mathrm{G}}\right)$ showed variation comparing the different $\mathrm{CPF}$ concentrations (Table 2). It was highest $\left(\mathrm{I}_{\mathrm{G}}=46\right)$ for the common carps exposed to $1.5 \mu \mathrm{g} \mathrm{CPF}$, followed by the one calculated for the fish treated with $3 \mu \mathrm{g}$ CPF $\left(\mathrm{I}_{\mathrm{G}}=44\right)$, but they were not significantly different $(\mathrm{p}>0.05)$. Significantly different were the gill indexes $\left(\mathrm{I}_{\mathrm{G}}\right)$ for the common carps exposed to the control and the lowest CPF concentrations compared to the other two ( $<<0.05)$. Evaluating these results in terms of the severity of the histological response, the gill index $\left(\mathrm{I}_{\mathrm{G}}\right)$ results of common carp were classified as Class II - normal tissue structure with moderate histological alterations for the lowest concentration and Class IV - pronounced histological alterations of the organ for the mean and highest concentration, respectively.

As for the percentage prevalence the gills were most affected in terms of the progressive alterations at all tested CPF concentrations (respectively $0.9,1.5$ and $3 \mu \mathrm{g}$ ) compared to the regressive and circulatory lesions (Table 3). In addition, the t-test proved significant differences $(\mathrm{p}<0.05)$ between the percentage prevalence of the progressive lesions compared to the other two gill histological patterns at all applied CPF concentrations. Significant differences were also found between the circulatory disturbances and progressive lesions at $0.9,1.5$ and $3 \mu \mathrm{g}$. In the control group we found only lamellar lifting which was presented in $16 \%$ of the observed samples.

\section{Respiration rate measurements}

The results from the respiration rate measurements are presented in Table 4.

Table 4. Index of respiration rate of common carp exposed to CPF concentrations at the $72^{\text {nd }}$ hour ( $n=5$ fish for each 30 l tank)

\begin{tabular}{|c|c|c|c|c|c|c|c|}
\hline \multirow{3}{*}{ CPF concentrations } & \multirow{3}{*}{$\begin{array}{c}\text { Fish weight. } \\
\mathrm{g}(\mathbf{G})\end{array}$} & \multicolumn{5}{|c|}{ Oxygen content $\left(\mathrm{mg} \mathrm{l}^{-1}\right)$} & \multirow{3}{*}{$\begin{array}{c}\text { Index of } \\
\text { respiration rate } \\
\text { (I) }\end{array}$} \\
\hline & & \multicolumn{2}{|c|}{ Start } & \multicolumn{2}{|c|}{ End } & \multirow{2}{*}{$\begin{array}{l}\text { Total } \\
\left(\mathbf{Q}_{2}\right)\end{array}$} & \\
\hline & & $\mathbf{q}$ & $\mathbf{Q}$ & $q_{1 h}$ & $Q_{1 h}$ & & \\
\hline \multicolumn{8}{|c|}{72 hour } \\
\hline Control & 71.3 & 6.4 & 192.00 & 6.1 & 183.00 & 9.00 & 0.126 \\
\hline $0.9 \mu \mathrm{g}$ & 64.7 & 6.2 & 186.00 & 5.9 & 177.00 & 9.00 & 0.139 \\
\hline $1.5 \mu \mathrm{g}$ & 54.5 & 5.9 & 177.00 & 5.6 & 168.00 & 9.00 & 0.165 \\
\hline $3 \mu \mathrm{g}$ & 59.5 & 5.9 & 177.00 & 5.5 & 165.00 & 12.00 & 0.202 \\
\hline
\end{tabular}

Overall, we determined that the fish increased its respiration rate most likely because $\mathrm{CPF}$ disrupted the gill histological structure and thus, destabilized the respiration process. At the end of the acute experiment $\left(72^{\text {nd }}\right.$ hour $)$ we recorded a 1.6 times increase in the respiration rate of the fish exposed to the highest $\mathrm{CPF}$ concentration, compared to the control. We also registered a strong correlation between the pesticide concentrations and the respiration rate index, although it was statistically insignificant $(\mathrm{r}=0.92, \mathrm{p}=$ 0.08). Furthermore, the index of determination showed that $84.64 \%$ of the observed correlation was probably caused by the CPF concentration. 


\section{Discussion}

\section{Water quality}

The results on the basic physical water properties showed a good agreement with the control. Therefore, we consider that the lesions in the gill histological structure and respiration rate measurements were not due to changes in the abiotic factors.

\section{Gill histology}

As described by Bernet et al. (1999) in some publications lesions were described only morphologically and in these studies the effects of water pollution correlated with the abundance of lesions found in the studied organ. However, other studies concentrated on a few alterations in the organ and assessed their extent by using a scale. With the quantification of the alterations, statistical evaluation becomes practicable. The corresponding indices can be compared more easily than the morphological descriptions of pathological changes. We agree with Bernet et al. (1999) that histology is a descriptive science and the assessment of morphological changes will always depend on the investigator's experience, but such a tool that we also used allows more reliable interpretation of the results and comparisons with others. Furthermore, to properly interpret results from histopathological evaluations, it is essential to realize that a healthy control condition is not characterized by the complete absence of any histological lesions, but may display moderate alterations such as minor structural disorders or mild inflammatory reactions (Bernet et al., 2004). In our study we only observed lamellar lifting in the gills of control common carp which was categorized as a mild lesion. We also share the opinion of Zimmerli et al. (2007) that a technical disadvantage of histology is its qualitative nature. For this reason, in the present study we applied the approach of Bernet et al. (1999) and Zimmerli et al. (2007) that developed an evaluation scheme to transform qualitative histological observations into a semi-quantitative index.

The gills are among the most delicate structures of the teleost body and are very sensitive to environmental conditions (Saraiva et al., 2015). We support the statement of Camargo and Martinez (2007) that by assessing the degree of expression of gill alterations, the extent of exposure to toxicants can be traced, given that the gills are involved in respiration, osmoregulation and excretion. They are an effective tool in biomonitoring studies also because of their large surface area that comes into contact with water, as well as their permeability (Evans et al., 2005; Vigliano et al., 2006). Therefore, the importance of gills in the respiration and ionic regulation of fish has led to many studies on the changes in this organ under the exposure of various environmental pollutants, including pesticides.

In the present experiment the degree of expression of lamellar lifting and edema was found to be mainly severe in the common carp gills. In addition, there was a clear proportional relationship found between the CPF concentrations and the degree of expression of these changes, and at the highest concentration they were severely expressed. Similarly to Jiang et al. (2011) we also consider that the most commonly found changes in gills under the action of toxicants are edema and lifting of the lamellar epithelium. However, they can serve as a protective mechanism because the separation of the epithelium from the lamellae increases the distance through which the pollutants in the water have to pass before they reach the bloodstream (Arellano et al., 2004). Lifting of the lamellar epithelium and edema were also found by other authors 
such as Girija et al. (2014) Babatunde et al. (2014) and Saraiva et al. (2015). Furthermore, Schmidt et al. (1999) and Bernet et al. (2004) also consider alterations such as branching of the secondary lamellae as an adaptation to low oxygen concentrations as it increased the surface area in brown trout after exposure to untreated sewage.

Proliferation of the epithelial tissue in the filament and in the secondary lamellae, as well as the glandular cells showed a difference in the degree of expression. We agree with Mallatt (1985) according to who epithelial tissue proliferation is one of the major alterations observed in fish gills in contaminated aquatic ecosystems. Similarly to Hassan (2011) we also consider that epithelial cell proliferation, partial fusion of secondary lamellae and lamellar lifting are protective mechanisms which increase the distance between the external environment and the blood, and this serves as a barrier to the entry of toxicants. Similar lesions in freshwater fish after pesticide contamination were found by Gabet et al. (2014). As for the most severe proliferative alteration, along with Butchiram et al. (2009) and Karthigayani et al. (2014), we also observed fusion as a result of activating epithelial cell division processes and hyperplasia of epithelial cells after exposure to pesticides leading to significant proliferative changes. We agree with Bentivegna et al. (2015) and Fonseca et al. (2017) that cell proliferation probably occurs as defense mechanisms, leading not only to increased epithelial thickness, but also in, extreme cases, to lamellar fusion. Indeed, the increased thickness of epithelium prevents further toxicant absorption, but on the other hand, this causes the adverse effect of compromising gas and ion exchange mechanisms (Fonseca et al., 2017).

In addition, along with hyperplastic epithelial areas reaching fusion, we also found such with thinning of the lamellae due to degenerative processes. The identified higher degree of observed degenerative changes at higher tested concentration confirmed the reduction and probably subsequent exclusion of compensatory-adaptive processes. However, we consider that the toxicant could act by simultaneously involving two processes - active cell division and degenerative-necrotic destruction. It is noteworthy that there was an inverse relationship between these lesions i.e when fusion was expressed in a more severe degree; the degenerative changes were in a lower one and vice versa. Furthermore, at the highest $\mathrm{CPF}$ concentration $(0.03 \mu \mathrm{g}=\mathrm{AA}-\mathrm{EQS})$ the degenerative processes were intensified and gradually shifted the proliferating ones. We consider that this would eventually affect the functioning of the organ, and could therefore inevitably cause oxidative stress and destabilize the health of the overallfish health. Our results confirmed the results of Theurkar et al. (2014) who found similar histological lesions, such as degeneration and necrosis of epithelial cells covering the filament, but at sublethal concentrations of insecticide monocrotophos. Together with the activation of compensatory-adaptive mechanisms associated with proliferative changes, we also found changes in the blood vessels of the gills of the experimental fish. At the lower concentrations, the histological changes were mild and with the increasing concentration, they shifted to moderate and severe.

The observed alterations, such as vasodilatation in the secondary lamellae and the main sinus were presented in varying degrees of expression, but we found a clear relationship between the impact and CPF concentration. The changes were found more frequently in the area of the venous sinus than in the secondary lamellae. Our results corresponded to those of Shubat et al. (1982) according to who vasodilation is observed mostly in the main sinus. In addition, we agree with Schwaiger et al. (2004) who suggested that the circulatory system alterations lead to a higher degree of 
stress-induced damage in the organism. On the other hand, according to McHugh et al. (2011) the circulatory disturbances and regressive alterations are generally regarded as reversible when the toxicant exposure stops.

\section{Respiration rate}

In terms of the other biomarker which we measured, the fish reacted by increasing their respiration rate with the increase of the pesticide concentrations after the $72^{\text {nd }}$ hour of exposure. We agree with Kumar et al. (2012) who suggested that in most cases the respiration rate increases with the increase of the pollutant concentration and level of toxicity. As stated by Stoyanova et al. (2017) and Yancheva et al. (2017b) the reason for this is that the organism tries to deliver more oxygen to all tissues and organs triggered by the oxidative stress due to the toxic exposure. Overall, our respiration rate measurements were in line with the histological lesions in the gills which confirmed that $\mathrm{CPF}$ affects negatively the respiration process and thus, physiology of common carp.

\section{Conclusions}

In sum, we can point out that the present study is a contribution in the field of pesticide contamination, especially for the short-term exposure effects of CPF on the physiology of commercially important fish species, such as common carp. Based on our results we can conclude that the gill changes which were identified were CPF related and $\mathrm{CPF}$ also affected the histology of carp gills by activating compensatory-adaptive and degenerative mechanisms leading to pathological alterations. In addition, the extent and prevalence of the proliferative alterations were predominant over the degenerative alterations, and those in the circulatory system. These changes subsequently changed the physiology of common carp by disrupting the gill function. Regardless of the applied concentrations the negative effects of CPF were also confirmed by the respiration intensity measurements. Moreover, the negative effect of $\mathrm{CPF}$ was observed at all three decreasing concentrations based on the permitted annual average concentrations (AA-EQS) in Directive 2013/39/EU which confirmed its toxicity on common carp. Overall, the results from the present study enhanced the importance of multi-biomarker approach in biomonitoring programs to assess the impact of organophosphorus pesticides on freshwater ecosystems. Thus, we strongly suggest that further studies in this particular area are continued.

Acknowledgements. The National program "Young Researches and Postdocs, 2018" financed by the Ministry of Education and Science, Bulgaria is highly appreciated. The authors also thank the Ministry for Education and Science, Bulgaria and The Scientific Research Fund for the financial support of project M26/6 (Scientific Fundamental Research for Young Scientists and Postdocs). We also thank the experts at the Regional Accredited Laboratory, Executive Environment Agency, Ministry of Environment and Water, Plovdiv, Bulgaria for providing the toxicant.

\section{REFERENCES}

[1] Abdel-Halim, K. Y., Salama, A. K., El-Khateeb, E. N., Bakry, N. M. (2006): Organophosphorus pollutants (OPP) in aquatic environment at Damietta Governorate, Egypt: implications for monitoring and biomarker responses. - Chemosphere 63: 14911498. 
[2] APHA. (2005): Standard methods for examination of water and wastewater, $21^{\text {st }}$ Ed. American Public Health Association, Washington, DC, USA.

[3] Arellano, J. M., Storch, V., Sarasquete, C. (2004): Ultrastructural and histochemical study on gills and skin of the Senegal sole, Solea senegalensis. - Journal of Applied Ichthyology 20: 452-460.

[4] Asselborn, V., Fernández, C., Zalocar, Y., Parodi, E. R. (2015): Effects of chlorpyrifos on the growth and ultrastructure of green algae, Ankistrodesmus gracilis. - Ecotoxicology and Environmental Safety 120: 334-341.

[5] Babatunde, M. M., Oladimeji, A. A., Rafindadi, A. H. (2014): Histopathological changes in the gills, livers and brains of $O$. niloticus (Trewavas) exposed to paraquat in chronic bioassay. - International Journal of Science and Technology 4(5): 101-110.

[6] Bentivegna, C. S., Cooper, K. R., Olson, G., Pena, E. A., Millemann, D. R., Portier, R. J. (2015): Chemical and histological comparisons between Brevoortia sp. (menhaden) collected in fall 2010 from Barataria Bay, LA and Delaware Bay, NJ following the Deep Water Horizon (DWH) oil spill. - Marine Environment Research 112: 21-34.

[7] Bernet, D., Schmidt, H., Meier, W., Burkhard-Holm, P., Wahli, T. (1999): Histopathology in fish: proposal for protocol to assess aquatic pollution. - Journal of Fish Diseases 22: 25-34.

[8] Bernet, D., Schmidt-Poshaus, H., Wahli, T., Burkhardt-Holm, P. (2004): Evaluation of two monitoring approaches to assess effects of waste water disposal on histological alterations in fish. - Hydrobiologia 524: 53-66.

[9] Brandt, C., Burnett, D. C., Arcinas, L., Palace, V., Anderson, W. G. (2015): Effects of chlorpyrifos on in vitro sex steroid production and thyroid follicular development in adult and larval Lake Sturgeon, Acipenser fulvescens. - Chemosphere 132: 179-187.

[10] Butchiram, M. S., Tilak, K. S., Raju, P. W. (2009): Studies on histopathological changes in the gill, liver and kidney of Channa punctatus (Bloch) exposed to alachlor. - Journal of Environmental Biology 30(2): 303-306.

[11] Camargo, M. M., Martinez, C. B. (2007): Histopathology of gills, kidney and liver of a Neotropical fish caged in an urban stream. - Neotropical Ichthyology 5: 327-336.

[12] Chen, L. H., Yang, J. L. (2007): Acute toxicity of antimony chloride and its effects on oxygen consumption of carp (Cyprinus carpio). - Bulletin of Environmental Pollution and Toxicology 78(6): 459-462.

[13] Chen, D., Zhang, Z., Yao, H., Liang, Y., Xu, H. S. (2015): Effects of atrazine and chlorpyrifos on oxidative stress-induced autophagy in the immune organs of common carp (Cyprinus carpio L.). - Fish \& Shellfish Immunology 44: 12-20.

[14] Colin, N., Porte, C., Fernandes, D., Barata, C., Padrós, F., Carrassón, M., Monroy, M., Cano-Rocabayera, O., de Sostoa, A., Piña, B., Maceda-Veiga, A. (2016): Ecological relevance of biomarkers in monitoring studies of macro-invertebrates and fish in Mediterranean rivers. - Science of the Total Environment 540: 307-323.

[15] Cruz, A. L. D., Prado, T. M., Maciel, L. A. d. S., Couto, R. D. (2015): Environmental effects on the gills and blood of Oreochromis niloticus exposed to rivers of Bahia, Brazil. - Ecotoxicology and Environmental Safety 111: 23-31.

[16] Directive 2000/60/EC of the European Parliament and of the Council of 23 October 2000 establishing a framework for Community action in the field of water policy.

[17] Directive 2010/63/EU of the European parliament and of the Council of 22 September 2010 on the protection of animals used for scientific purposes.

[18] Directive 2013/39/EU of the European Parliament and of the Council of 12 August 2013 amending Directives 2000/60/EC and 2008/105/EC as regards priority substances in the field of water policy.

[19] Dobreva, V., Tsekov, A., Velcheva, I. (2008): Study of the effect of zinc on gill functions of the Prussian carp Carassius gibelio Bloch. - Bulgarian Journal of Agricultural Science 14(2): 182-185. 
[20] DWAF. Department of Water Affairs and Forestry (1996): South African Water Quality Guidelines. - Pretoria, South Africa.

[21] Evans, D. H., Piermarini, P. M., Choe, K. P. (2005): The multifunctional fish gill: dominant site of gas exchange, osmoregulation, acid-base regulation, and excretion of nitrogenous waste. - Physiological Reviews 85: 97-177.

[22] Fang, H., Yu, Y. L., Wang, X. G., Chu, X. Q., Pan, X. D., Yang, X. E. (2008): Effects of repeated applications of chlorpyrifos on its persistence and soil microbial functional diversity and development of its degradation capability. - Bulletin of Environmental Contamination and Toxicology 81: 397-400.

[23] FAO. Fisheries and Aquaculture Department (2016): The State of World Fisheries and Aquaculture. - Food and Agriculture Organization of the United Nations, Rome, Italy.

[24] Fevery, D., Houbraken, M., Spanoghe, P. (2016): Pressure of non-professional use of pesticides on operators, aquatic organisms and bees in Belgium. - Science of the Total Environment 550: 514-521.

[25] Fonseca, A. R., Sanches Fernandes, L. F., Fontainhas-Fernandes, A., Monteiro, S. M., Pacheco, F. A. L. (2016): From catchment to fish: impact of anthropogenic pressures on gill histopathology. - Science of the Total Environment 550: 972-986.

[26] Fonseca, A. R., Sanches Fernandes, L. F., Fontainhas-Fernandes, A., Monteiro S. M., Pacheco F. A. L. (2017): The impact of freshwater metal concentrations on the severity of histopathological changes in fish gills: A statistical perspective. - Science of the Total Environment 599-600: 217-226.

[27] Fowler, J., Cohen, L., Jarvis, P. (1998): Practical statistics for field biology. - John Wiley and Sons. Chichester, England.

[28] Gabet, S. H., Abbas, W. T., Authman, M. M. N., Gaber, S. A. (2014): Histological and biochemical studies on some organs of two fish species in Bardawil Lagoon, North Sinai, Egypt. - Global Veterinaria 12(1): 1-11.

[29] Gautier, J.-Ch. (2011): Drug Safety Evaluation: Methods and Protocols, Methods in Molecular Biology, Vol. 691. - Springer Science+Business Media, Switzerland.

[30] Girija, R., Shahila, I., Deepthi, P., Sreedevi, O., Preepthi, V., Meena, M., Lalitha, M., Krishnapryia, K., Suchitra, P. B., Thushara, N. R. (2014): Histopathological alterations in the gill architecture of freshwater fish, Labeo rohita exposed to sublethal doses of monocrotophos. - International Journal of Toxicology and Applied Pharmacology 4(3): 45-50.

[31] Grube, A., Donaldson, D., Kiely, T., Wu, L. (2011): Pesticides industry sales and usage: 2006 and 2007 Market Estimates. - Biological and Economic Analysis Division, Office of Pesticide Programs. U.S. Environmental Protection Agency, Washington, DC, USA.

[32] Hammer, O., Harper, D., Ryan P. (2001): PAST PAleontological STatistical software package for education and data analysis. - Paleontologia Electronica 4(1): 9. Available at: http://folk.uio.no/ohammer/past.

[33] Hassan, B. K. (2011): The effect of copper and cadmium on oxygen consumption of the juvenile common carp, Cyprinus carpio (L.). - Mesopotamian Journal of Marine Science 26(1): 25-34.

[34] Hermoso, V., Clavero, M. (2013): Revisiting ecological integrity 30 years later: nonnative species and the misdiagnosis of freshwater ecosystem health. - Fish Fisheries 14: 416-423.

[35] Hinton, D. E., Laurén, D. J. (1990): Integrative histopathological approaches to detecting effects of environmental stressors on fishes. - American Fisheries Society Symposium 8: 51-66.

[36] Humason, G. L. (1962): Animal Tissue Techniques, fourth ed. - Freeman and Company, New York, USA. 
[37] Humphrey, C. A., Klumpp, D. W., Raethke, N. (2004): Ambon damsel (Pomacentrus amboinensis) as a bioindicator organism for the Great Barrier Reef: responses to chlorpyrifos. - Bulletin of Environmental Contamination and Toxicology 72: 888-895.

[38] Jiang, J., Gu, X., Song, R., Zhang, Q., Geng, J., Wang, X., Yang, L. (2011): Timedependent oxidative stress and histopathological changes in Cyprinus carpio L. exposed to microcystin-LR. - Ecotoxicology 20: 1000-1009.

[39] Karthigayani, T., Denis, M., Remy, A. R. A., Shettu, N. (2014): Effect of cypermethrin toxicity in the gills of the fish Oreochromis mossambicus. - Journal of Modern Biotechnology 3(3): 35-41

[40] Katsumata, M., Koikke, T., Nishikawa, M., Kazumura, K., Tsuchiya, H. (2006): Rapid ecotoxicological bioassay using delayed fluorescence in the green algal Pseudokircneriella subcapitata. - Water Research 40: 3393-3400.

[41] Kong, S., Dong, C., Lv, H., Chen, L., Zhang, J., Pu, F., Li, X., Xu, P. (2018): Genome wide identification of taste receptor genes in common carp (Cyprinus carpio) and phylogenetic analysis in teleost. - Gene 678: 65-72.

[42] Kumar, S., Pandey, R. K., Das, S., Das, V. K. (2012): Dimehoate alters respiratory rate and gill histopathology in freshwater mussel Lamellidens marginatus (Lamarck). Journal of Applied Biosciences 38(2): 154-158.

[43] Kumar, U., Berliner J., Adak, T., Rath, P. C., Dey, A., Pokhare, S. S., Jambhulkar, N. N., Panneerselvam, P., Kumar, A., Mohapatra, S. D. (2017): Non-target effect of continuous application of chlorpyrifos on soil microbes, nematodes and its persistence under subhumid tropical rice-rice cropping system. - Ecotoxicology and Environmental Safety 135: 225-235.

[44] Kwong, T. C. (2002): Organophosphate pesticides: biochemistry and clinical toxicology. - Therapeutic Drug Monitoring 24: 144-149.

[45] Lee, B. C., Kim, K. T., Cho, J. G., Lee, J. W., Ryu, T. K., Yoon, J. H., Lee, S. H., Duong, C. N., Eom, I. C., Kim, P. J., Choi, K. H. (2012): Oxidative stress in juvenile common carp (Cyprinus carpio) exposed to $\mathrm{TiO}_{2}$ nanoparticles. - Molecular and Cellular Toxicology 8: 357-366.

[46] Liu, L., Xu, Y., Xu, L., Wang, J., Wu, W., Xu, L., Yan, Y. (2015): Analysis of differentially expressed proteins in zebra fish (Danio rerio) embryos exposed to chlorpyrifos. - Comparative Biochemistry and Physiology 167: 183-189.

[47] McHugh, K. J., Smit, N. J., Van Vuren, J. H. J., Van Dyk, J. C., Bervoets, L., Covaci, A., Wepener, V. (2011): A histological-based fish health assessment of the tigerfish, Hydrocynus vittatus from a DDT-affected area. - Physics and Chemistry of the Earth 36: 895-904.

[48] Mallatt, J. (1985): Fish gill structural changes induced by toxicants and other irritants: a statistical review. - Canadian Journal of Aquatic Sciences 42: 630-648.

[49] Marino, D., Ronco, A. (2005): Cypermethrin and chlopyrifos concentration levels in surface water bodies of the Pampa Ondulada, Argentina. - Bulletin of Environmental Contamination and Toxicology 75(4): 820-826.

[50] Mugni, H., Paracampo, A., Demetrio, P., Pardi, M., Bulus, G., Ronco, A., Bonetto, C. (2016): Toxicity persistence of chlorpyrifos in runoff from experimental soybean plots to the non-target amphipod Hyalella curvispina: effect of crop management. - Bulletin of Environmental Contamination and Toxicology 70(2): 257-264.

[51] Nguyen, T. T., Berg, H., Nguyen, H. T. T., Nguyen, C. V. (2015): Effects of chlorpyrifos ethyl on acetylcholinesterase activity in climbing Perch cultured in rice fields in the Mekong Delta, Vietnam. - Ecotoxicology and Environmental Safety 117: 34-40.

[52] Nishida, Y. (2011): The chemical process of oxidative stress by copper (II) and iron (III) ions in several neurodegenerative disorders. - Monatshefte fur Chemie 142: 375-384.

[53] OECD Test No. 203 (1992): Fish, Acute Toxicity Test. - Organisation for Economic Cooperation and Development, Paris, France. 
[54] Pandey, S., Parvez, S., Ansari, R. A., Ali, M., Kaur, M., Hayat, F., Ahmad, F., Raisuddin, S. (2008): Effects of exposure to multiple trace metals on biochemical, histological and ultrae structural features of gills of a freshwater fish, Channa punctata Bloch. - ChemicoBiological Interactions 174: 183-192.

[55] Pereira, S., Pinto, A. L., Cortes, R., Fontaínhas-Fernandes, A., Coimbra, A. M., Monteiro, S. M. (2013): Gill histopathological and oxidative stress evaluation in native fish captured in Portuguese northwestern rivers. - Ecotoxicology and Environmental Safety 90: 157166.

[56] Pirsaheb, M., Azadi, N. A., Miglietta, M. L., Sayadi, M. H., Blahova, J., Fathi, M., Mansouri, B. (2019): Toxicological effects of transition metal-doped titanium dioxide nanoparticles on goldfish (Carassius auratus) and common carp (Cyprinus carpio) Chemosphere 215: 904-915.

[57] Rajeshkumar, S., Liu, Y., Ma, J., Duan, H. Y., Li, X. (2017): Effects of exposure to multiple heavy metals on biochemical and histopathological alterations in common carp, Cyprinus carpio L. - Fish \& Shellfish Immunology 70: 461-472.

[58] Rao, J. V., Begum, G., Pallela, R., Usman, P. K., Rao, R. N. (2005): Changes in behaviour and brain acetylcholinesterase activity in mosquito fish, Gambusia affinis in response to the sub-lethal exposure to chlorpyrifos. - International Journal of Environmental Research and Pub. Health 2: 478-483.

[59] Rosseland, B. O., Massabuau, J. C., Grimalt, J., Hofer, R., Lackner, R., Raddum, G., Rognerud, S., Vives, I. (2003): Fish Ecotoxicology: European Mountain Lake Ecosystems Regionalisation, DiaGnostic and Socio-economic Evaluation (EMERGE). Fish Sampling Manual for Live Fish. - Norwegian Institute for Water Research (NIVA), Oslo, Norway.

[60] Saraiva, A., Costa, J., Serrão, J., Cruz, C., Eiras, J. C. (2015): A histology-based fish health assessment of farmed seabass (Dicentrarchus labrax L.). - Aquaculture 448: 375381.

[61] Schmidt, H., Bernet, D., Wahli, T., Burkhardt-Holm, P. (1999): Active biomonitoring with brown trout and rainbow trout in diluted sewage plant effluents. - Journal of Fish Biology 54: 585-596.

[62] Schwaiger, J., Ferling, H., Mallow, U., Wintermayr, H., Negele, R. D. (2004): Toxic effects of the non-steroidal anti-inflammatory drug diclofenac. Part I. Histopathological alterations and bioaccumulation in rainbow trout. - Aquatic Toxicology 68: 141-150.

[63] Shubat, P. J., Poirier, S. H., Knuth, M. L., Brooke, L. T. (1982): Acute toxicity of tetrachloroethylene and tetrachloroethylene with dimethyl formamide to rainbow trout (Salmo gairdneri). - Bulletin of Environmental Contamination and Toxicology 28: 7-10.

[64] Solomon, K. R., Williams, W. M., Mackay, D., Purdy, J.,Giddings, J. M., Giesy, J. P. (2014): Properties and uses of chlorpyrifos in the United States. - In: Giesy, J. P., Solomon, K. R. (eds.) Ecological risk assessment for chlorpyrifos in terrestrial and aquatic systems in the United States. Springer Science+Business Media, Switzerland.

[65] Stoyanova, S. G., Velcheva, I. G., Yancheva, V. S., Mollov, I., Georgieva, E. S. (2017): Biomarkers for ex situ $\mathrm{Ni}$ and $\mathrm{Pb}$ exposure in common carp (Cyprinus carpio L.). - Acta Zoologica Bulgarica Suppl. 8: 163-168.

[66] Streit, B., Kuhn, K. (1994): Effects of organophosphorous insecticides on auto-chthonous and introduced Gammarus species. - Water Science and Technology 29: 233-240.

[67] Tchounwou, P. B., Yedjou, C. G., Patlolla, A. K., Sutton, D. J. (2012): Heavy metal toxicity and the environment. - Experientia supplementum 101: 133-164.

[68] Theurkar, S. V., Gaikwad, A. N., Ghadake, M. K., Patil, S. B. (2014): Monocrotophos on the histopathological changes in the gills of mosquito fish, Gambusia affinis. - Research Journal of Recent Sciences 3: 29-32. 
[69] Topal, A., Atamanalp, M., Oruç, E., Kırıcı, M., Kocaman, E. M. (2014): Apoptotic effects and glucose-6-phosphate dehydrogenase responses in liver and gill tissues of rainbow trout treated with chlorpyrifos. - Tissue and Cell 46: 490-496.

[70] Topal, A., Oruç, E., Altun, S., Ceyhun, S. B., Atamanalp, M. (2015): The effects of acute boric acid treatment on gill, kidney and muscle tissues in juvenile rainbow trout. Journal of Applied Animal Research 44(1): 297-302.

[71] Tsekov, A. (1989): Studies on transferrin polymorphism in carp and its resistance to oxygen deficiency. - Genetics and Selection 22(6): 517-522. (In Bulgarian).

[72] USEPA U.S. Environmental Protection Agency (1986): Ambient Water Quality Criteria for Chlorpyrifos. - Washington, DC, USA.

[73] Van der Oost, R., Beyer, J., Vermeulen, N. P. (2003): Fish bioaccumulation and biomarkers in environmental risk assessment: a review. - Environmental Toxicology and Pharmacology 13: 57-149.

[74] Varó, I., Serrano, R., Navarro, J. C., Lopez, F. J., Amat, F. (1998): Acute lethal toxicity of the organophosphorus pesticide chlorpyrifos to different species and strains of Artemia. - Bulletin of Environmental Contamination and Toxicology 61: 778-785.

[75] Vigliano, F. A., Aleman, N., Quiroga, M. I., Nieto, J. M. (2006): Ultrastructural characterization of gills in juveniles of the Argentinian silverside, Odontesthes bonariensis (Valenciennes, 1835) (Teleostei: Atheriniformes). - Anatomia, Histologia, Embryologia 35: 76-83.

[76] Wang, C., Zhang, Z., Yao, H., Zhao, F., Wang, L., Wang, X., Xing, H., Xu, S. (2014): Effects of atrazine and chlorpyrifos on DNA methylation in the liver, kidney and gill of the common carp (Cyprinus carpio L.). - Toxicology 259: 1-9.

[77] Xing, H., Li, S., Wang, Z., Gao, X., Xu, S., Wang X. (2012): Histopathological changes and antioxidant response in brain and kidney of common carp exposed to atrazine and chlorpyrifos. - Chemosphere 88: 377-383.

[78] Yancheva, V., Mollov, I., Velcheva, I., Stoyanova, S., Todorova, K., Georgieva, E. (2017a): Lysosomal membrane stability and respiration rate in zebra mussel (Dreissena polymorpha Pallas, 1771) as biomarkers for ex situ heavy metal exposure. - Periodicum Biologorum 119(4): 229-237.

[79] Yancheva, V., Mollov, I., Georgieva, E., Stoyanova, S., Tsvetanova, V., Velcheva, I. (2017b): Ex situ effects of Chlorpyrifos on the lysosomal membrane stability and respiration rate in zebra mussel, Dreissena polymorpha (Pallas, 1771). - Acta Zoologica Bulgarica Suppl. 8: 85-90.

[80] Yu, K., Li, G., Feng, W., Liu, L., Zhang, J., Wu, W., Xu, L., Yan, Y. (2015): Chlorpyrifos is estrogenic and alters embryonic hatching, cell proliferation and apoptosis in zebrafish. - Biological Interactions 239: 26-33.

[81] Zimmerli, S., Bernet, D., Burkhardt-Holm, P., Schmidt-Posthaus, H., Vonlanthen, P., Wahli, T., Segner, H. (2007): Assessment of fish health status in four Swiss rivers showing a decline in brown trout catches. - Aquatic Sciences 69: 11-25.

[82] Zoral, M. A., Futami, K., Endo, M., Maita, M., Katagiri, T. (2017): Anthelmintic activity of Rosmarinus officinalis against Dactylogyrus minutus (Monogenea) infections in Cyprinus carpio. - Veterinary Parasitology 247: 1-6. 